\title{
Faktor Lingkungan Yang Berhubungan Dengan Keberadaan Jentik Anopheles Berdasarkan Ketinggian Wilayah Di Kabupaten Timor Tengah Selatan Tahun 2015
}

\author{
Maria Benadete Bete Seban ${ }^{\text {a*, }}$ Pius weraman ${ }^{\text {a }}$, Jauhari Effendi a \\ a Mahasiswa Pascasarjana Fakultas Kesehatan Masyarakat Universitas Nusa Cendana Kupang \\ *Email: samaramine@gmail.com
}

Diterima (received) 18 Januari 2019; disetujui (accepted) 29 Juli 2019; tersedia secara online (available online) 1 Agustus 2019

\begin{abstract}
Malaria is an endemic disease in Timor Tengah Selatan. The data of Annual Parasite Incidence (API) 2014 showed that there were $8.2 / 1000$ population who were infected by this disease. It is still above the national rate of 5/1000 of the population. Cases of malaria spread in almost all areas of health centers with different topographic characteristics that allow the Anopheles larvae breeding sites with different characteristics. The study was conducted to determine the factors of physical environment and biological environment that influence the existence of Anopheles larvae in breeding sites based on topographic characteristics of Timor Tengah Selatan. This study applied across-sectional study approach. The research activities were started by sampling health centers and villages locations. The locations were determined representation of the three characteristics of the topography region, namely lowland (coastal region), plains (the hills) and highland (mountain region). Of 18 variables observed, there are two variables that significantly have relationship with the existence of the Anopheles larvae in breeding sites, namely (1) water depth brood with an average depth $0,5682 \mathrm{~m}, \mathrm{p}$ value of 0.000 and (2) water clarity brood with p value 0.045 at $95 \%$ CI 1.172 to 30.725 . Some variables show that: the average of air temperature is $31.82^{\circ} \mathrm{C}$, the average of water temperature is $25.73{ }^{\circ} \mathrm{C}$, the average of $\mathrm{PH}$ water is 8.1 , the average of air humidity is 72.55 . A total of $63.6 \%$ breeding sites is directly exposed to sun, $81.8 \%$ of breeding sites is stagnant water, the average of area of breeding sites is $4.0682 \mathrm{~m}^{2}$, a total of $63.3 \%$ of breeding sites there is water all the year, a total of $50 \%$ of breeding sites is clear water, a total of $100 \%$ location found public activities there and at all locations, there are no mangrove sand algae. Based on topography region, the most breeding sites of Anopheles larvae found in the coastal region (lowland). It is recommended to list and eliminate all potential breeding sites of Anopheles larvae. District Health Office should control the activity plan and intervention schedule of health centers to eliminate Anopheles larvae breeding sites. During dry season, the society should control to dry the puddles too.
\end{abstract}

Keywords: Anopheles larvae, topography

\section{Abstrak}

Malaria merupakan salah satu penyakit endemis di Kabupaten Timor Tengah Selatan. Angka Annual Parasite Incidence (API) Tahun 2014 sebesar 8,2/1000 penduduk. Angka ini masih berada diatas angka nasional sebesar 5/1000 penduduk. Kasus malaria menyebar di hampir semua wilayah Puskesmas dengan karakteristik topografi yang berbeda dan memungkinkan adanya tempat perindukan jentik dengan karakteristik yang berbeda-beda pula. Penelitian dilakukan untuk mengetahui faktor-faktor lingkungan fisik dan lingkungan biologi yang mempengaruhi keberadaan jentik Anopheles di tempat perindukan berbasis ketinggian wilayah di Kabupaten Timor Tengah Selatan. Penelitian ini menggunakan pendekatan study Cross-sectional. Kegiatan penelitian dimulai dari penentuan lokasi dengan melakukan sampling lokasi puskesmas dan desa. Penentuan lokasi memperhatikan adanya keterwakilan dari tiga karakteristik topografi wilayah yaitu dataran rendah (wilayah pantai), dataran sedang (wilayah perbukitan) dan dataran tinggi (wilayah pegunungan). Dari 18 variabel penelitian yang diteliti, terdapat 2 variabel yang secara signifikan berhubungan dengan keberadaan jentik Anopheles

doi: https://doi.org/10.24843/blje.2019.v19.i02.p02 
pada tempat perindukan yaitu (1) kedalaman air perindukan dengan kedalaman rata-rata 0,5682 $\mathrm{m}$ dan nilai p value 0,000 dan (2) kejernihan air perindukan dengan $\mathrm{p}$ value 0,045 pada $95 \% \mathrm{CI}=1,172-30,725$. Keadaan beberapa variabel sebagai berikut: suhu udara rata-rata adalah $31,82^{\circ} \mathrm{C}$, suhu air rata-rata $25,73^{\circ} \mathrm{C}, \mathrm{PH}$ air rata-rata 8,1 , kelembaban udara rata-rata 72,55 . Sebanyak $63,6 \%$ tempat perindukan langsung terkena sinar matahari, $81,8 \%$ tempat perindukan airnya tergenang. Luas perindukan rata-rata $4,0682 \mathrm{~m}^{2}$, sebanyak $63,3 \%$ perindukan ada air sepanjang tahun, $50 \%$ lokasi airnya jernih, $100 \%$ lokasi perindukan ada aktifitas masyarakat dan pada semua lokasi tidak ditemukan adanya tanaman bakau dan ganggang. Tempat penelitian yang paling banyak ditemukan adanya jentik Anopheles berdasarkan topografi adalah di wilayah Pantai Puskesmas Kualin. Disarankan agar ada intervensi terhadap tempattempat potensial perindukan jentik Anopheles. Kontrol Dinkes dilakukan dengan memantau rencana kegiatan dan jadwal intervensi setiap puskesmas. Masyarakat agar selalu diingatkan untuk memantau dan melakukan intervensi terhadap tempat-tempat perindukan potensial seperti genangan-genangan kecil dari sungai/kali yang hampir kering pada saat menjelang mulai surut/keringnya tempat-tempat tersebut.

Kata Kunci: jentik Anopheles; topografi

\section{Pendahuluan}

Kabupaten timor tengah selatan merupakan salah satu Kabupaten di Propinsi Nusa Tenggara Timur dengan letak wilayah geografis yang memungkinkan adanya tempat perindukan jentik dengan karakteristik yang berbeda-beda pula. Di Kabupaten Timor Tengah Selatan periode tahun 2011 s.d. 2014 menunjukkan tren penurunan Annual Parasite Incidence (API) namun masih berada di atas standar Angka API nasional. Pada tahun 2011 angka API sebesar 25/1000 penduduk, Tahun 2012 sebesar 17/1000 penduduk, Tahun 2013 sebesar 9/1000 penduduk sedangkan Tahun 2014 sebesar 8,2/1000 penduduk. Angka API beberapa puskesmas tahun 2014 sebagai berikut; Puskesmas Boking 90/1000 penduduk, Panite 11,3/1000 penduduk, Kota SoE 11,1/1000 penduduk, Noemuke 10,1/1000 penduduk, Kualin 16/1000 penduduk, Niki-Niki 4,8/1000 penduduk, Fatumnutu 5,2/1000 penduduk dan Kapan 1,3/1000 penduduk. Dari beberapa puskesmas tersebut, yang wilayahnya merupakan daerah dataran rendah adalah Puskesmas Boking, Panite, Noemuke dan Kualin; sedangkan yang berada di dataran sedang adalah Puskesmas Kota SoE dan NikiNiki; sedangkan dataran tinggi adalah Puskesmas Kapan dan Fatumnutu.

Kasus malaria yang menyebar di hampir semua wilayah puskesmas dengan kondisi karakteristik topografi yang berbeda memungkinkan adanya tempat perindukan nyamuk dengan karakteristik yang berbeda-beda pula. Dengan adanya perbedaan topografi wilayah maka ada keadaan lingkungan fisik dan lingkungan biologi berbeda pada tempat perindukan nyamuk yang mempengaruhi keberadaan jentik Anopheles. Sehubungan dengan keadaan tersebut, maka penelitian ini bertujuan untuk mengetahui faktorfaktor lingkungan fisik dan lingkungan biologi tempat perindukan nyamuk berdasarkan ketinggian wilayah yang mempengaruhi keberadaan jentik Anopheles di Kabupaten Timor Tengah Selatan.

\section{Metode Penelitian}

Penelitian ini menggunakan pendekatan studi Cross-sectional. Kegiatan penelitian dimulai dari penentuan lokasi dengan melakukan sampling lokasi Puskesmas dan desa. Penentuan lokasi memperhatikan adanya keterwakilan dari tiga karakteristik topografi wilayah yaitu dataran rendah (wilayah pantai), dataran sedang (wilayah perbukitan) dan dataran tinggi (wilayah pegunungan). Setelah penentuan lokasi desa maka dilakukan identifikasi dan pemetaan terhadap semua jenis serta jumlah tempat perindukan nyamuk potensial di wilayah desa.

\subsection{Populasi dan Sampel Penelitian}

1. Populasi Sasaran/ Reference Population

Populasi sasaran dalam penelitian ini adalah tempat perindukan nyamuk berdasarkan stratifikasi topografi wilayah puskesmas dan desa di Kabupaten Timor Tengah Selatan Tahun 2014.

2. Populasi Studi 
Lokasi tempat perindukan nyamuk di 3 wilayah desa yang berasal dari 3 wilayah puskesmas terpilih yaitu wilayah Pantai Puskesmas Kualin, Desa Oemaman dan Desa Tuafanu; wilayah Perbukitan yaitu Puskesmas Niki-Niki, Desa Niki-Niki dan Desa Nobi-Nobi; serta Pegunungan Puskesmas Kapan yaitu Desa Eonbesi dan Desa Obesi.

3. Sampel Penelitian

Pemilihan sampel lokasi penelitian diambil secara acak dengan Stratified Random Sampling. Pemilihan sampel dilakukan secara proporsional dengan dua tahap, dimana tahap pertama adalah pemilihan sampel puskesmas dan tahap kedua adalah pemilihan desa yang berasal dari puskesmas terpilih. Penentuan lokasi puskesmas dan desa yang akan masuk atau diikutkan dalam sampling wilayah dilakukan dengan memperhatikan angka kasus malaria. Puskesmas dan desa dengan angka API 0 (nol) selama periode tahun 2014, tidak diikutkan dalam penentuan sampling lokasi penelitian.

Sampel penelitian berada di 3 (tiga) wilayah kecamatan (tiga wilayah puskesmas) dengan masingmasing kecamatan 2 (dua) desa. Lokasi penelitian meliputi Kecamatan Kualin, Desa Oemaman dan Desa Tuafanu, sedangkan Kecamatan Amanuban Tengah, Desa Niki-Niki dan Desa Nobi-Nobi. Untuk Kecamatan Mollo Utara, Desa Eonbesi dan Desa Obesi. Ketiga wilayah kecamatan ini mewakili karakteristik ketinggian wilayah di Kabupaten Timor Tengah Selatan (dataran rendan, sedang dan tinggi).

\section{Hasil dan Pembahasan}

\subsection{Keberadaan Jentik Anopheles}

Pada enam desa lokasi penelitian ditemukan 60 tempat potensial perindukan jentik Anopheles yang menjadi subyek dalam penelitian ini. Dari jumlah tersebut, sebanyak 11 tempat perindukan ditemukan jentik Anopheles (18,3\%), sedangkan lainnya ditemukan jentik lain atau tidak ada jentik.

\subsection{Tempat Perindukan Anopheles}

Tabel 1. Jumlah Tempat Perindukan Anopheles

\begin{tabular}{|c|c|c|c|c|c|c|c|}
\hline \multirow{2}{*}{ No } & \multirow{2}{*}{$\begin{array}{c}\text { Karakeristik } \\
\text { Topografi }\end{array}$} & \multirow{2}{*}{ Puskesmas } & \multirow{2}{*}{ Desa } & \multicolumn{2}{|c|}{ Tempat Perindukan } & \multicolumn{2}{|c|}{ Ada Jentik Anopheles } \\
\hline & & & & Jlh & $\%$ & Jlh & $\%$ \\
\hline \multirow{2}{*}{1} & \multirow{2}{*}{$\begin{array}{l}\text { Dataran Tinggi } \\
\text { (pegunungan) }\end{array}$} & \multirow{2}{*}{ Niki-niki } & Eonbesi & 10 & 16,7 & 3 & 27,3 \\
\hline & & & Obesi & 9 & 15,0 & 0 & 0 \\
\hline \multirow[b]{2}{*}{2} & \multirow{2}{*}{$\begin{array}{l}\text { Dataran Sedang } \\
\text { (perbukitan) }\end{array}$} & \multirow[b]{2}{*}{ Kapan } & Niki-Niki & 10 & 16,7 & 1 & 9,05 \\
\hline & & & $\begin{array}{l}\text { Nobi- } \\
\text { Nobi }\end{array}$ & 13 & 21,7 & 1 & 9,05 \\
\hline \multirow{2}{*}{3} & \multirow{2}{*}{$\begin{array}{l}\text { Dataran Rendah } \\
\text { (pantai) }\end{array}$} & \multirow{2}{*}{ Kualin } & Oemaman & 9 & 15,0 & 3 & 27,3 \\
\hline & & & Tuafanu & 9 & 15,0 & 3 & 27,3 \\
\hline & Total & 3 & 6 & 60 & 100,0 & 11 & 100,0 \\
\hline
\end{tabular}

Berdasarkan Karakteristik Topografi Di Wilayah Kabupatan Timor Tengah Selatan Tahun 2015

Dari 6 (enam) lokasi desa, tempat perindukan terbanyak yang ditemukan berasal dari desa Nobi-Nobi dengan 13 lokasi (21,7\%). Untuk lokasi dimana ditemukan adanya jentik Anopheles, secara berurutan berdasarkan tempat perindukan terbanyak masing-masing adalah Desa Eonbesi, Oemaman dan Tuafanu masing-masing sebesar 27,3\% (3 lokasi), sedangkan untuk Desa Nobi-Nobi dan kelurahan Niki-Niki masing-masing sebesar 9,05\% (1 lokasi). Berdasarkan karakteristik topografi wilayah, persentase wilayah dengan jentik Anopheles positif terbanyak pada dataran rendah (pantai) yaitu 54,6\% (6 lokasi). Pada daerah dataran tinggi (pegunungan) persentase lokasi ditemukan jentik sebesar 27,3\% (3 lokasi) dan dataran sedang adalah $18,1 \%$ (2 lokasi). 
MBB Seban, dkk.; Faktor Lingkungan Yang Berhubungan Dengan Keberadaan Jentik.....

Tabel 2. Jenis Tempat Perindukan Anopheles

\begin{tabular}{|c|c|c|c|c|c|c|c|c|c|}
\hline \multirow{3}{*}{ No } & \multirow{3}{*}{ Jenis } & \multicolumn{6}{|c|}{ Topografi } & \multicolumn{2}{|c|}{ Total } \\
\hline & & \multicolumn{2}{|c|}{$\begin{array}{c}\text { Dataran Tinggi } \\
\text { (pegunungan) }\end{array}$} & \multicolumn{2}{|c|}{$\begin{array}{c}\text { Dataran Sedang } \\
\text { (perbukitan) }\end{array}$} & \multicolumn{2}{|c|}{$\begin{array}{c}\text { Dataran Rendah } \\
\text { (pantai) }\end{array}$} & \multirow[t]{2}{*}{ Jlh } & \multirow[t]{2}{*}{$\%$} \\
\hline & & Jlh & $\%$ & Jlh & $\%$ & Jlh & $\%$ & & \\
\hline 1 & Bak & 0 & 0 & 0 & 0 & 1 & 16,7 & 1 & 9,1 \\
\hline 2 & Drum & 0 & 0 & 0 & 0 & 0 & 0 & 0 & 0 \\
\hline 3 & Tambak & 0 & 0 & 0 & 0 & 0 & 0 & 0 & 0 \\
\hline 4 & Rawa-Rawa & 1 & 33,3 & 1 & 50 & 0 & 0 & 2 & 18,2 \\
\hline 5 & Sawah & 1 & 33,3 & 0 & 0 & 0 & 0 & 1 & 9,1 \\
\hline 6 & Genangan & 1 & 33,3 & 1 & 50 & 2 & 33,3 & 4 & 36,4 \\
\hline 7 & Kali & 0 & 0 & 0 & 0 & 3 & 50 & 3 & 27,3 \\
\hline 8 & Sumur & 0 & 0 & 0 & 0 & 0 & 0 & 0 & 0 \\
\hline \multirow[t]{2}{*}{9} & Mata Air & 0 & 0 & 0 & 0 & 0 & 0 & 0 & 0 \\
\hline & Total & 3 & 100 & 2 & 100 & 6 & 100 & 11 & 100 \\
\hline
\end{tabular}

Berdasarkan Karakteristik Topografi Wilayah Di Wilayah Kabupatan Timor Tengah Selatan Tahun 2015

Jenis perindukan terbanyak adalah genangan $(36,4 \%)$ dan kali $(27,3 \%)$. Berdasarkan topografi wilayah, perindukan Anopheles terbanyak ditemukan pada daerah dataran rendah (pantai) dengan jumlah 6 (enam) tempat perindukan dan tiga lokasi diantaranya adalah kali yang hampir kering dan hanya menyisakan sedikit air.

Keberadaan vektor dipengaruhi oleh kondisi lingkungan fisik dan lingkungan biologi dimana vektor tersebut berada. Dalam Ririh, Y. (2011) dikatakan tempat jentik Anopheles adalah genangan-genangan air. Lingkungan fisik yang terkait dengan keberadaan jentik Anopheles diantaranya adalah suhu, kelembaban udara, keadaan air tempat perindukan sedangkan untuk lingkungan biologi terkait dengan keadaan tanaman air dan keberadaan predator jentik di tempat perindukan. Hasil uji statistik dari 18 (delapan belas) variabel penelitian ini menunjukan bahwa terdapat 2 (dua) variabel yang secara signifikan mempengaruhi keberadaan jentik Anopheles pada tempat perindukan. Kedua variabel tersebut adalah (1) kedalaman air perindukan dan (2) kejernihan air perindukan.

\subsection{Hubungan antara Suhu Udara dengan Keberadaan Jentik Anopheles}

Untuk lokasi dimana ditemukan adanya jentik Anopheles, suhu udara rata-rata adalah $31,82{ }^{\circ} \mathrm{C}$ sedangkan suhu minimum $28{ }^{\circ} \mathrm{C}$ dan suhu maksimum $39{ }^{\circ} \mathrm{C}$. Keadaan suhu maksimum dan minimum ini tidak menunjukan adanya perbedaan dengan kondisi suhu secara keseluruhan di semua tempat perindukan pada lokasi penelitian.

Tabel 3. Distribusi Rata-Rata Suhu Udara

\begin{tabular}{ccccccc}
\hline \multirow{3}{*}{ Suhu Udara } & Keberadaan Jentik Anopheles & Mean & SD & SE & P Value & N \\
\cline { 2 - 6 } & Tidak Ada & 31,86 & 2,051 & 0,293 & & 49 \\
& Ada & 31,82 & 2,926 & 0,882 & & 11 \\
\hline
\end{tabular}

Menurut Keberadaan Jentik Anopheles Di Wilayah Kabupatan Timor Tengah Selatan Tahun 2015

Rata-rata suhu udara pada lokasi dimana ditemukan ada jentik maupun tidak ada jentik menunjukan tidak adanya perbedaan yang berarti dimana pada lokasi yang ada jentik suhu udaranya $31,82^{\circ} \mathrm{C}$ sedangkan pada lokasi yang tidak ditemukan adanya jentik Anopheles angka suhunya sebesar $31,86^{\circ} \mathrm{C}$. Hasil uji 
statistik didapatkan nilai $\mathrm{p}=0.958$ yang berarti bahwa pada alpha $5 \%$ tidak terlihat adanya perbedaan signifikan rata-rata suhu udara pada lokasi dimana ditemukan jentik dengan lokasi yang tidak ditemukan adanya jentik.

Beberapa hasil penelitian sebelumnya menunjukan adanya karakteristik suhu tertentu yang mempengaruhi keberadaan jentik maupun nyamuk Anopheles dewasa pada suatu lokasi. Penelitian Ernamaiyanti, dkk (2010) di Desa muara kelanta menemukan bahwa kondisi ekologis yang cocok untuk vektor malaria adalah pada suhu $33,83^{\circ} \mathrm{C}$ sampai dengan $34,17^{\circ} \mathrm{C}$. Hasil penelitian Chwatt juga munjukan bahwa suhu udara optimum bagi kehidupan nyamuk berkisar antara $25^{\circ} \mathrm{C}-30^{\circ} \mathrm{C}$ dan pertumbuhan akan berhenti sama sekali bila suhu kurang dari $10^{\circ} \mathrm{C}$ atau lebih dari $40^{\circ} \mathrm{C}$.

\subsection{Hubungan antara Suhu Air dengan Keberadaan Jentik Anopheles}

Suhu air berada pada kisaran $20^{\circ} \mathrm{C}$ s.d. $31^{\circ} \mathrm{C}$ dengan suhu rata-rata sebesar $24,77^{\circ} \mathrm{C}$. Rata-rata keadaan suhu air lebih rendah dari suhu udara. Untuk keadaan suhu air dimana ditemukan adanya entik Anopheles, suhu air maksimum adalah $29^{\circ} \mathrm{C}$ sedangkan suhu air minimum adalah $23^{\circ} \mathrm{C}$ dengan rata-rata $25,73^{\circ} \mathrm{C}$.

Hasil uji statistik didapatkan nilai rata-rata suhu air yang ada jentik sebesar $25,73^{\circ} \mathrm{C}$, sedangkan pada tempat perindukan yang tidak ada jentik suhu airnya $24,55^{\circ} \mathrm{C}$. Dengan nilai $\mathrm{P}$ value 0,147 menunjukan bahwa tidak adanya perbedaan yang berarti rata-rata suhu air pada lokasi ditemukan adanya jentik Anopheles dan lokasi yang tidak ditemukan adanya jentik Anopheles.

Hasil penelitian sejalan dengan Depkes RI (2001) bahwa suhu optimum untuk breeding site nyamuk berkisar antara $25-27^{\circ} \mathrm{C}$. Hasil penelitian dari Bustan, dkk. (2012) yang menggambarkan bahwa Desa Bulubete Kecamatan Dolo Selatan dengan kondisi daerah dataran rendah mempunyai curah hujan rata-rata 2000 - $3000 \mathrm{~mm}$ pertahun memberikan kontribusi besar terjadinya berbeda cuaca dengan daerah lain, hal ini berdampak pada suhu yang berpotensi sebagai faktor pendukung terjadinya peningkatan populasi densitas larva nyamuk Anopheles sebagai vektor Malaria. Dikatakan bahwa suhu merupakan salah satu faktor lingkungan abiotik yang memberikan kontribusi besar bagi perkembangbiakan larva Anopheles pada semua breeding site walaupun dalam kapasitas tingkat densitas larva yang berbeda, berdasarkan hasil pengukuran suhu dari 13 titik berkisar suhu antara $26-33^{\circ} \mathrm{C}$ dengan klasifikasi yang positif terdapat larva suhunya berkisar $29-33^{\circ} \mathrm{C}$ dan yang tidak ada larva suhunya berkisar $26-29^{\circ} \mathrm{C}$. Menurut Hoedojo (1993) suhu optimum untuk breeding site nyamuk berkisar antara $20-28^{\circ} \mathrm{C}$. Suhu pada semua breeding site nyamuk di Desa Bulubete dalam penelitian ini termasuk tinggi, lebih tinggi dari suhu optimum 2,5. Namun bila dibandingkan dengan hasil penelitian Syarif (2003), suhu breeding site nyamuk di Desa Sukajaya Lempasing berkisar antara $31,9-33,6^{\circ} \mathrm{C}$. Hal ini menunjukkan bahwa suhu tertinggi tersebut relatif sama, kesesuaian hasil pengukuran suhu yang tinggi di Desa Bulubete dan Desa Sukajaya diduga dipengaruhi oleh musim kemarau dengan penyinaran relatif terus menerus oleh sinar matahari. Menurut Raharjo, dkk. (2003) suhu di sekitar breeding site nyamuk Anopheles sp. pada musim kemarau dapat mencapai 31,1 $36,7^{\circ} \mathrm{C}$. Hal tersebut menunjukan bahwa suhu tinggi ini terjadi saat musim kemarau, sedangkan suhu yang diperoleh Hoedojo (1993) diduga karena penelitiannya dilakukan pada musim hujan. Bahwa suhu suatu daerah tidak tergantung pada musim semata tetapi faktor letak geogafis, keadaan topografi, ketinggian tempat turut mempengaruhi suhu oleh karena tiap kenaikan ketinggian 100 meter maka selisih suhu udara dengan tempat sebelumnya adalah $0,5^{\circ} \mathrm{C}$ (Depkes RI, 2001), hal ini berdampak pula pada suhu breeding site.

\subsection{Hubungan antara PH dengan Keberadaan Jentik Anopheles}

PH air tempat perindukan berada pada kisaran 3,1 s/d 12,0 dengan PH rata-rata 8,1. Pada tempat perindukan yang terdapat jentik Anopheles, PH air berada pada kisaran 4,1 s/d 10,5 dengan rata-rata 6,4. Ada perbedaan rata-rata antara lokasi yang ada jentik dengan keseluruhan lokasi sebesar 1,7. Untuk nilai $\mathrm{pH}$ air tempat perindukan, hasil uji statistik menunjukan rata-rata $\mathrm{PH}$ air pada perindukan yang ditemukan jentik Anopheles sebesar 7,873, sedikit lebih rendah dari tempat perindukan yang tidak ditemukan adanya jentik Anopheles $(8,151)$. Dengan nilai p value sebesar 0,685 menunjukan bahwa tidak ada perbedaan 
bermakna $\mathrm{pH}$ air pada tempat perindukan yang ditemukan jentik anpheles dengan tempat perindukan yang tidak ditemukan jentik Anopheles.

Pada lokasi perindukan jentik Anopheles $\mathrm{pH}$ air berada pada kisaran 4,1 s/d 10,5 dengan rata-rata sebesar 6,4. Hasil penelitian ini tidak menunjukan adanya hubungan yang berarti antara $\mathrm{pH}$ dengan keberadaan jentik Anopheles, berbeda dengan beberapa penelitian sebelumnya yang menemukan adanya perbedaan tersebut. Bustan, dkk. (2012) dalam penelitiannya menemukan bahwa $\mathrm{pH}$ air mempunyai peranan penting bagi perkembangbiakan larva nyamuk Anopheles. Larva nyamuk Anopheles dapat hidup pada $\mathrm{pH}$ yang rendah yaitu $\mathrm{pH}$ di bawah 7 (tujuh). Semakin tinggi $\mathrm{pH}$ melebihi $\mathrm{pH}$ yang optimum untuk perkembangbiakan nyamuk maka larva akan mati. $\mathrm{pH}$ air sangat dipengaruhi olah musim, hal ini berdampak pada kehidupan nyamuk Anopheles. Sedangkan hasil penelitian Hermendo (2009) menunjukan bahwa pH 6,4-6,7 sangat mendukung perkembangbiakan vektor Malaria. Effendi (2003), mengatakan bahwa sebagian besar biota akuatik menyukai nilai pH antara 7-8,57. Menurut Syarif (2003) larva Anopheles memiliki toleransi terhadap pH antara 7,91-8,09. Raharjo dkk. (2003) juga menyatakan bahwa pH breeding site nyamuk Anopheles pada musim kemarau berkisar antara 6,8 - 8,66.

\subsection{Hubungan antara Kelembaban Udara dengan Keberadaan Jentik Anopheles}

Kelembaban udara terendah sebesar 55 sedangkan kelembaban udara tertinggi sebesar 97 dengan ratarata 73,33. Untuk lokasi yang ada jentik Anopheles, kelembaban udara terendah adalah 55 dan kelembaban udara tertinggi adalah 97 dengan rata-rata sebesar 72,55. Perbedaan hanya ada pada kelembaban rata-rata. Untuk hubungan antara kelembaban udara dengan keberadaan jentik Anopheles, hasil uji statistik menunjukan selisih rata-rata kelembaban udara pada tempat perindukan yang ada jentik Anopheles dan tidak ada jentik Anopheles terdapat perbedaan dengan selisih kurang dari satu. Nilai P Value sebesar 0,747 menunjukan bahwa dengan tingkat kepercayaan sebesar 95\% tidak terdapat perbedaan kelembaban udara pada lokasi perindukan dimana ditemukan jentik Anopheles dengan tempat perindukan yang tidak ada jentik Anopheles.

Kelembaban udara rata-rata pada lokasi perindukan Anopheles sebesar 72,55\% terendah adalah 55 dan kelembaban udara tertinggi adalah 97 dengan rata-rata sebesar 72,55. Perbedaan hanya ada pada kelembaban rata-rata. Penelitian Ria Nurfitrianah, dkk, menemukan kondisi kelembaban tempat perindukan yang kondusif sebagai perindukan Anopheles adalah antara 60\%-80\%, sedangkan tingkat kelembaban $60 \%$ merupakan batas yang paling rendah untuk memungkinkan hidupnya nyamuk. Hasil ini diperkuat lagi oleh penelitian Raharjo (2003) di lereng barat dan timur pegunungan Muria Jawa Tengah, dimana suhu $>60 \%$ sebagai pendukung untuk tumbuh dan berkembang spesies Anopheles aconitus. Jenis spesies nyamuk ini pernah juga ditemukan oleh peneliti dari Loka Litbang Baturaja Propinsi Sumatera Selatan ada di lokasi penelitian. Kelembaban yang rendah memperpendek umur nyamuk, meskipun tidak berpengaruh pada parasit. Tingkat kelembaban $60 \%$ merupakan batas paling rendah untuk memungkinkan hidupnya nyamuk.

\subsection{Hubungan antara Sinar Matahari dengan Keberadaan Jentik Anopheles}

Sebagian besar lokasi perindukan tidak terkena sinar matahari secara langsung (55\%). Untuk perindukan yang ada jentik, kondisi sinar matahari menyinari secara langsung sebesar 63,6\% (7 lokasi).

Tabel 4. Keberadaan Jentik Anopheles

\begin{tabular}{cccccc}
\hline $\begin{array}{c}\text { Matahari Langsung Menyinari } \\
\text { Tempat Perindukan }\end{array}$ & \multicolumn{2}{c}{ Keberadaan Jentik Anopheles } & Total & $\begin{array}{c}\text { OR } \\
\text { (95\% CI) }\end{array}$ & $\begin{array}{c}\text { P } \\
\text { value }\end{array}$ \\
\cline { 2 - 3 } Ya & 7 & Tidak & & 27 & \\
\\
\multirow{2}{*}{ Tidak } & $25,9 \%$ & $74,1 \%$ & $100,0 \%$ & 2,538 & \\
& 4 & 29 & 33 & $(0,655-$ & 0,299 \\
Total & $12,1 \%$ & $87,9 \%$ & $100,0 \%$ & $9,829)$ & \\
\hline
\end{tabular}




$18,3 \% \quad 81,7 \% \quad 100,0 \%$

Berdasarkan Keadaan Sinar Matahari Di Wilayah Kabupatan Timor Tengah Selatan Tahun 2015

Hasil analisis hubungan antara keadaan sinar matahari dengan keberadaan jentik Anopheles di lokasi perindukan diperoleh gambaran bahwapada lokasi dimana matahari langsung menyinari tempat perindukan diketahui 74,1\% tidak ditemukan jentik Anopheles sedangkan pada lokasi dimana matahari tidak langsung menyinari tempat perindukan 87,9\% lokasi tidak ditemukan adanya jentik Anopheles. Hasil uji statistik diperoleh nilai $\mathrm{p}=0,299$, maka dapat disimpulkan bahwa tidak ada perbedaan proporsi keberadaan jentik Anopheles pada tempat perindukan dimana matahari langsung menyinari tempat perindukan dan lokasi yang tidak langsung disinari matahari.

Pada lokasi tempat perindukan dimana ditemukan terdapat jentik,sebagian besar $(63,6 \%)$ lokasi, sinar matahari menyinari secara langsung sebesar $25,9 \%$. Hasil uji statistik menunjukan tidak adanya hubungan yang signifikant antara keadaan sinar matahari dengan keberadaan jentik Anopheles di tempat perindukan. Keadaan ini berbeda dengan pendapat Ririh, Y. (2011) bahwa sinar matahari sedikit banyak berpengaruh terhadap pertumbuhan dan perkembangan larva nyamuk vektor. Sebagai contoh An. sundaicus menyukai tempat yang teduh, tetapi An. hyrcanus menyukai tempat yang terbuka, sedangkan larva An. barbirostis dapat hidup baik ditempat teduh maupun yang terbuka dan terkena sinar matahari langsung An. balabacensis menyukai tempat yang teduh di hutan untuk beristirahat dan berlindung dari sinar matahari yang menyinari langsung.

\subsection{Hubungan antara Keadaan Aliran Air dengan Keberadaan Jentik Anopheles}

Air tempat perindukan di lokasi penelitian sebagian besar tergenang/tidak mengalir (80\%). Pada lokasi ditemukan adanya jentik Anopheles, prosentase perindukan yang airnya tergenang sebesar 81,8\% (9 lokasi).

Tabel 5. Keberadaan Jentik Anopheles

\begin{tabular}{|c|c|c|c|c|c|}
\hline \multirow{2}{*}{$\begin{array}{l}\text { Air Tergenang/ } \\
\text { Tidak Mengalir }\end{array}$} & \multicolumn{2}{|c|}{ Keberadaan Jentik Anopheles } & \multirow{2}{*}{ Total } & \multirow{2}{*}{$\begin{array}{c}\text { OR } \\
(95 \% \mathrm{CI})\end{array}$} & \multirow{2}{*}{$P$ value } \\
\hline & $\mathbf{Y a}$ & Tidak & & & \\
\hline \multirow{2}{*}{$\mathrm{Ya}$} & 9 & 39 & 48 & \multirow{6}{*}{$\begin{array}{c}1,154 \\
(0,215- \\
6,205)\end{array}$} & \multirow{6}{*}{1,000} \\
\hline & $18,8 \%$ & $81,3 \%$ & $100,0 \%$ & & \\
\hline Tidak & 2 & 10 & 12 & & \\
\hline Пиак & $16,7 \%$ & $83,3 \%$ & $100,0 \%$ & & \\
\hline \multirow{2}{*}{ Total } & 11 & 49 & 60 & & \\
\hline & $18,3 \%$ & $81,7 \%$ & $100,0 \%$ & & \\
\hline
\end{tabular}

Berdasarkan Keadaan Aliran Air Tempat Perindukan Di Wilayah Kabupatan Timor Tengah Selatan Tahun 2015

Hubungan antara keadaan aliran air dan keberadaan jentik di lokasi perindukan diperoleh bahwa pada lokasi yang air tergenang/tidak mengalir $81,3 \%$ tidak ditemukan jentik sedangkan pada lokasi yang airnya mengalir sebanyak $83,3 \%$ juga tidak ditemukan adanya jentik. Hasil uji statistik diperoleh nilai $\mathrm{P}=1,000$ yang menunjukan bahwa tidak ada perbedaan proporsi keberadaan jentik Anopheles pada lokasi yang airnya tergenang/tidak mengalir dengan lokasi yang airnya mengalir.

\subsection{Hubungan antara Lantai Dasar Perindukan dengan Keberadaan Jentik Anopheles}

Keadaan tempat perindukan Anopheles sebagian besar lantai bersentuhan langsung dengan tanah $(90,9 \%)$. Dari total 11 perindukan anpheles yang ditemukan, terdapat satu lokasi dimana perindukannya adalah bak yang lantainya tidak langsung bersentuhan dengan tanah. 
MBB Seban, dkk.; Faktor Lingkungan Yang Berhubungan Dengan Keberadaan Jentik.....

Tabel 6. Keberadaan Jentik Anopheles

\begin{tabular}{|c|c|c|c|c|c|}
\hline \multirow{2}{*}{$\begin{array}{c}\text { Lantai Dasar Bersentuhan } \\
\text { dengan Tanah }\end{array}$} & \multicolumn{2}{|c|}{ Keberadaan Jentik Anopheles } & \multirow{2}{*}{ Total } & \multirow{2}{*}{$\begin{array}{c}\text { OR } \\
(95 \% \mathrm{CI})\end{array}$} & \multirow{2}{*}{$P$ value } \\
\hline & Ya & Tidak & & & \\
\hline \multirow{2}{*}{$\mathrm{Ya}$} & 10 & 35 & 45 & \multirow{6}{*}{$\begin{array}{c}4,000 \\
(0,467- \\
34,238)\end{array}$} & \multirow{6}{*}{0,335} \\
\hline & $22,2 \%$ & $77,8 \%$ & $100,0 \%$ & & \\
\hline Tidak & 1 & 14 & 15 & & \\
\hline поак & $6,7 \%$ & $93,3 \%$ & $100,0 \%$ & & \\
\hline \multirow{2}{*}{ Total } & 11 & 49 & 60 & & \\
\hline & $18,3 \%$ & $81,7 \%$ & $100,0 \%$ & & \\
\hline
\end{tabular}

Berdasarkan Keadaan Lantai Dasar Perindukan Di Wilayah Kabupatan Timor Tengah Selatan Tahun 2015

Pada lokasi dimana lantai dasar perindukan bersentuhan langsung dengan tanah, sebanyak 35 tempat perindukan (77,8\%) tidak ditemukan jentik Anopheles, sedangkan pada lokasi yang lantai tidak bersentuhan langsung dengan tanah 93,3\% juga tidak ditemukan adanya jentik Anopheles. Terdapat 1 (satu) tempat perindukan yang lantai dasar tidak bersentuhan langsung dengan tanah dimana ditemukan adanya jentik Anopheles. Hasil uji statistik dengan nilai $\mathrm{p}=1,000$ menunjukan tidak ada hubungan yang signifikan antara keadaan lantai dasar perindukan dengan keberadaan jentik Anopheles di lokasi perindukan.

\subsection{Hubungan antara Luas Perindukan dengan Keberadaan Jentik Anopheles}

Tempat perindukan yang ada memiliki luas terendah $0,1 \mathrm{~m}^{2}$ dan tertinggi $20 \mathrm{~m}^{2}$ dengan rata-rata 3,51 $\mathrm{m}^{2}$. Luas perindukan dimana jentik ditemukan, rata-rata 4,0682 $\mathrm{m}^{2}$ sedangkan luas terendah adalah $0,25 \mathrm{~m} 2$ dan luas maksimum adalah $10,0 \mathrm{~m} 2$.

Tabel 7. Distribusi Rata-Rata Luas Tempat

\begin{tabular}{ccccccc}
\hline \multirow{2}{*}{ Luas Tempat } & Keberadaan Jentik Anopheles & Mean & SD & SE & P Value & N \\
\cline { 2 - 6 } Perindukan & Tidak Ada & 3,3857 & 5,13387 & 0,73341 & & 49 \\
& Ada & 4,0682 & 4,00327 & 1,20703 & 0,681 & 11 \\
\hline
\end{tabular}

Perindukan Menurut Keberadaan Jentik Anopheles Di Wilayah Kabupatan Timor Tengah Selatan Tahun 2015

Analisis hubungan antara luas tempat perindukan dengan keberadaan jentik Anopheles di tempat perindukan menunjukkan bahwa rata-rata perbedaan luas tempat perindukan kurang dari satu. Dengan nilai $\mathrm{P}$ value sebesar 0,681 maka dikatakan tidak ada perbedaan luas tempat perindukan pada tempat perindukan yang ada jentik Anopheles dengan tempat perindukan yang tidak ada jentik Anopheles.

\subsection{Hubungan antara Kedalaman Perindukan dengan Keberadaan Jentik Anopheles}

Kedalaman perindukan berada pada kisaran 0,1 m s.d. 9,0 m dengan kedalaman rata-rata sebesar 1,76 m. Untuk kedalaman pada lokasi yang ada jentik Anopheles rata-rata 0,5682 m dengan kedalaman maksimum $1 \mathrm{~m}$ dan minimum $0,1 \mathrm{~m}$. Ada perbedaan rata-rata kedalaman perindukan yang ada jentik dengan perindukan secara keseluruhan dengan angka-angka lebih dari 1 meter.

Rata-rata kedalaman tempat perindukan pada lokasi perindukan yang tidak ada jentik adalah 2,0224 m, sedangkan pada lokasi yang ada jentik Anopheles adalah 0,5682 m dengan kisaran 0,1 m sampai dengan $1 \mathrm{~m}$. Dengan nilai P value sebesar 0,000 maka dengan tingkat kepercayaan 95\% dapat dikatakan bahwa ada perbedaan yang bermakna rata-rata kedalaman tempat perindukan pada lokasi perindukan yang ada jentik Anopheles dan lokasi perindukan yang tidak ada jentik Anopheles.

Jentik Anopheles ditemukan pada perindukan potensial dengan kedalaman yang rendah. Hasil penelitian ini sejalan dengan penelitian sebelumnya oleh Brown (1979) dan Setyaningrum et al. (2008) 
yang menemukan bahwa perairan yang potensial sebagai habitat vektor malaria adalah tempat dengan kedalaman air $\leq 1 \mathrm{~m}$. Penelitian Ernamaiyanti, Kasry,A,dkk (2010) di Desa Muara Kelanta menemukan jentik Anopheles berada pada perindukan dengan kedalaman air 0,24 m sampai dengan 0,95 m. Pada kedalaman air diatas 1 (satu) m tidak ditemukan jentik Anopheles. Kedalaman air ini terkait dengan tempat jentik tersebut ditemukan, dimana sebagian besar berupa genangan-genangan kecil (bekas tapak binatang) dan kali yang airnya hampir kering.

\subsection{Hubungan antara Sifat Perindukan dengan Keberadaan Jentik Anopheles}

Memperhatikan karakteristik keberadaan tempat perindukan yang ada, sebagian besar menetap atau selalu ada sepanjang tahun (63,3\%). Kondisi perindukan yang bersifat temporer/sementara sebesar 36,7\%.

Tabel 8. Keberadaan Jentik Anopheles

\begin{tabular}{|c|c|c|c|c|c|}
\hline \multirow{2}{*}{ Musiman/Sementara } & \multicolumn{2}{|c|}{ Keberadaan Jentik Anopheles } & \multirow{2}{*}{ Total } & \multirow{2}{*}{$\begin{array}{c}\text { OR } \\
(95 \% \mathrm{CI})\end{array}$} & \multirow{2}{*}{$P$ value } \\
\hline & Ya & Tidak & & & \\
\hline \multirow{2}{*}{ Ya } & 6 & 16 & 22 & \multirow{6}{*}{$\begin{array}{c}2,475 \\
(0,656- \\
9,344)\end{array}$} & \multirow{6}{*}{0,310} \\
\hline & $27,3 \%$ & $72,7 \%$ & $100,0 \%$ & & \\
\hline Tidak & 5 & 33 & 38 & & \\
\hline & $13,2 \%$ & $86,8 \%$ & $100,0 \%$ & & \\
\hline \multirow{2}{*}{ Total } & 11 & 49 & 60 & & \\
\hline & $18,3 \%$ & $81,7 \%$ & $100,0 \%$ & & \\
\hline
\end{tabular}

Berdasarkan Sifat Tempat Perindukan Di Wilayah Kabupaten Timor Tengah Selatan Tahun 2015

Analisis hubungan antara keadaan sifat tempat perindukan dengan keberadaan jentik Anopheles di lokasi perindukan menunjukkan bahwa sebanyak 72,7\% lokasi yang hanya sementara atau bersifat musiman/sementara tidak ditemukan jentik Anopheles, sedangkan pada lokasi yang airnya ada/mengalir sepanjang tahun sebanyak 33 lokasi $(86,8 \%)$ tidak ditemukan adanya jentik Anopheles. Dengan nilai $\mathrm{P}$ value 0,310 maka dengan tingkat kepercayaan $95 \%$ dapat dikatakan bahwa tidak ada perbedaan berarti antara sifat tempat perindukan dengan keberadaan jentik Anopheles di lokasi perindukan.

\subsection{Hubungan antara Kejernihan Air Perindukan dengan Keberadaan Jentik Anopheles}

Keadaan fisik air tidak menunjukkan perbedaan jumlah, dimana tempat perindukan yang airnya keruh/bercampur lumpur dan yang terlihat jernih/bersih persentasenya sama yaitu $50 \%$.

Tabel 9. Keberadaan Jentik Anopheles

\begin{tabular}{|c|c|c|c|c|c|}
\hline \multirow{2}{*}{$\begin{array}{c}\text { Air Keruh/ } \\
\text { Bercampur Lumpur }\end{array}$} & \multicolumn{2}{|c|}{ Keberadaan Jentik Anopheles } & \multirow{2}{*}{ Total } & \multirow{2}{*}{$\begin{array}{c}\text { OR } \\
(95 \% \mathrm{CI}) \\
\end{array}$} & \multirow{2}{*}{$P$ value } \\
\hline & Ya & Tidak & & & \\
\hline \multirow{2}{*}{$\mathrm{Ya}$} & 9 & 21 & 30 & \multirow{6}{*}{$\begin{array}{c}6,000 \\
(1,172- \\
30,725)\end{array}$} & \multirow{6}{*}{0,045} \\
\hline & $30,0 \%$ & $70,0 \%$ & $100,0 \%$ & & \\
\hline Tidak & 2 & 28 & 30 & & \\
\hline & $6,7 \%$ & $93,3 \%$ & $100,0 \%$ & & \\
\hline \multirow{2}{*}{ Total } & 11 & 49 & 60 & & \\
\hline & $18,3 \%$ & $81,7 \%$ & $100,0 \%$ & & \\
\hline
\end{tabular}

Berdasarkan Keadaan Air Tempat Perindukan Di Wilayah Kabupaten Timor Tengah Selatan Tahun 2015 
Hubungan antara keadaan air dengan keberadaan jentik Anopheles menunjukkan bahwa dari 30 tempat perindukan yang diketahui airnya keruh/bercampur lumpur, sebanyak 21 perindukan (70\%) tidak ditemukan jentik Anopheles, sedangkan dari jumlah yang sama (30 lokasi) yang airnya jernih/tidak bercampur lumpur sebanyak 28 perindukan $(93,3 \%)$ tidak ditemukan adanya jentik Anopheles. Nilai P value sebesar 0,045 menunjukkan bahwa dengan tingkat kepercayaan 95\% ada hubungan antara keadaan air dengan keberadaan jentik Anopheles di tempat perindukan. Dengan 95\% CI=1,172-30,725 dan nilai OR sebesar 6,000 maka dapat dikatakan bahwa tempat perindukan dengan air yang keruh berpeluang 6 kali lebih besar untuk ditemukan jentik dibanding dengan tempat perindukan dengan air jernih/tidak bercampur lumpur.

Sebagian besar lokasi perindukan Anopheles, fisik airnya keruh (81,8\%). Hasil uji juga menunjukkan adanya hubungan/keterkaitan antara kejernihan air dengan ada/tidaknya jentik pada tempat perindukan. Hasil ini sejalan dengan penelitian dari Bustan, dkk. (2012) di Desa Bulubete Kecamatan Dolo Selatan dimana jentik Anopheles lebih dominan ditemukan pada genangan air berupa kubangan dengan kondisi air yang keruh pada kedalaman air berkisar $10-20 \mathrm{~cm}$. Sedangkan hasil penelitian Kazwaini (2006) menunjukkan bahwa breeding site potensial bagi perkembangbiakan nyamuk adalah air dengan kondisi keruh maupun jernih. Penelitian Boewono (2004) juga menemukan bahwa genangan air di kebun salak berupa parit yang banyak sampah dan daun atau pelepah salak berpotensi sebagai breeding site Anopheles sepanjang tahun. Sedangkan Soekirno dkk (1997) dalam penelitiannya di Halmahera menemukan lokasi perindukan jentik Anopheles berada pada air yang jernih.

\subsection{Hubungan antara Jarak Perindukan dengan Keberadaan Jentik Anopheles}

Untuk variabel jarak perindukan dengan perumahan terdekat, rata-rata 17,55m dengan jarak terdekat $1 \mathrm{~m}$ dan jarak terjauh $60 \mathrm{~m}$. Pada lokasi jentik ditemukan, jarak perindukan rata-rata adalah $27 \mathrm{~m}$ dengan jarak terdekat $2 \mathrm{~m}$ dan terjauh $60 \mathrm{~m}$. Ada perbedaan jarak rata-rata antara lokasi ditemukan adanya jentik dengan lokasi keseluruhan.

\subsection{Hubungan antara Aktivitas Masyarakat dengan Keberadaan Jentik Anopheles}

Keadaan di sekitar perindukan menunjukkan bahwa sebagian besar lokasi perindukan ada aktivitas masyarakat (93,3\%). Aktivitas dimaksud berupa lokasi perindukan adalah lokasi perumahan, tempat mengambil air, kebun dan aktivitas lainnya.

Tabel 10. Keberadaan Jentik Anopheles

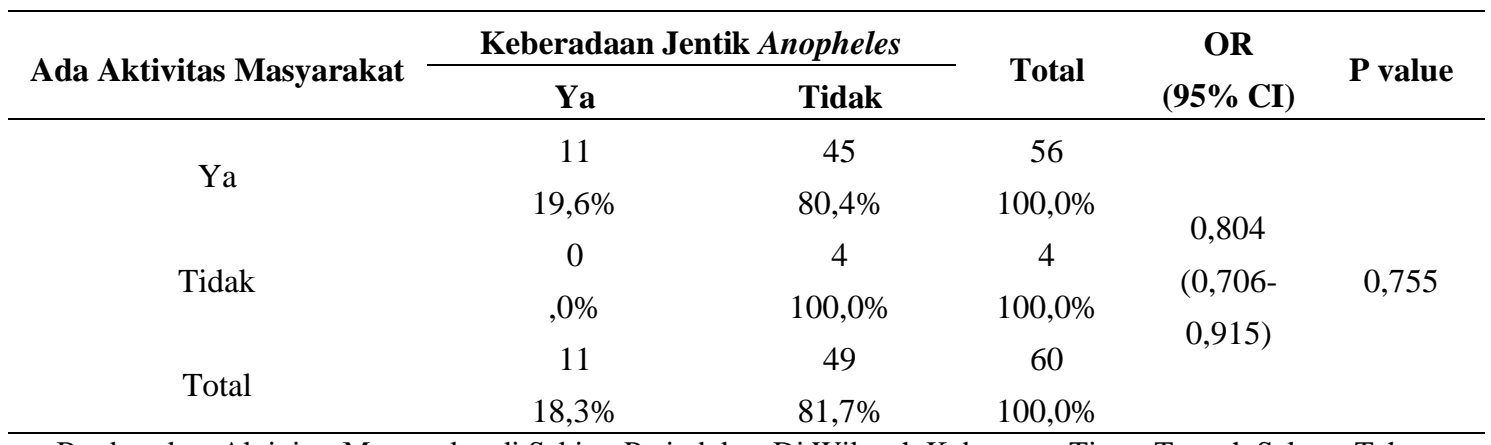

Berdasarkan Aktivitas Masyarakat di Sekitar Perindukan Di Wilayah Kabupaten Timor Tengah Selatan Tahun 2015

Hasil analisis hubungan antara aktivitas masyarakat di sekitar perindukan dengan keberadaan jentik Anopheles di tempat perindukan menunjukan bahwa dari total 56 perindukan dimana ada aktivitas masyarakat, sebanyak 45 perindukan $(80,4 \%)$ tidak ditemukan adanya jentik. Sedangkan pada lokasi dimana tidak ditemukan adanya aktivitas masyarakat $100 \%$ tidak ditemukan adanya jentik Anopheles. Nilai 
$\mathrm{P}$ value sebesar 0,755 menunjukkan tidak adanya hubungan antara aktivitas masyarakat di sekitar perindukan dengan keberadaan jentik Anopheles di tempat perindukan.

\subsection{Hubungan antara Tanaman Bakau dengan Keberadaan Jentik Anopheles}

Pada lokasi perindukan Anopheles, tidak ditemukan adanya tanaman bakau, sedangkan dari total 60 tempat perindukan di lokasi penelitian, tanaman bakau ditemukan pada 1 (satu) lokasi.

Tabel 11. Keberadaan Jentik Anopheles

\begin{tabular}{|c|c|c|c|c|c|}
\hline \multirow{2}{*}{ Tanaman Bakau } & \multicolumn{2}{|c|}{ Keberadaan Jentik Anopheles } & \multirow{2}{*}{ Total } & \multirow{2}{*}{$\begin{array}{c}\text { OR } \\
(95 \% \mathrm{CI})\end{array}$} & \multirow{2}{*}{$P$ value } \\
\hline & $\mathrm{Ya}$ & Tidak & & & \\
\hline \multirow{2}{*}{ Ada } & 0 & 1 & 1 & \multirow{6}{*}{$\begin{array}{r}1,229 \\
(1,088- \\
1,389)\end{array}$} & \multirow{6}{*}{1,000} \\
\hline & $0 \%$ & $100,0 \%$ & $100,0 \%$ & & \\
\hline Tidak Ada & 11 & 48 & 59 & & \\
\hline & $18,6 \%$ & $81,4 \%$ & $100,0 \%$ & & \\
\hline \multirow{2}{*}{ Total } & 11 & 49 & 60 & & \\
\hline & $18,3 \%$ & $81,7 \%$ & $100,0 \%$ & & \\
\hline
\end{tabular}

Analisis hubungan antara adanya tanaman bakau dengan keberadaan jentik Anopheles di tempat perindukan menunjukkan bahwa dari total 60 tempat perindukan, satu lokasi ditemukan adanya tanaman bakau dan pada lokasi tersebut tidak ditemukan adanya jentik Anopheles. Sedangkan pada lokasi yang tidak ada tanaman bakau, sebanyak 48 tempat perindukan $(81,7 \%)$ tidak ditemukan adanya jentik Anopheles. Nilai $P$ value sebesar 1,000 menunjukkan tidak adanya perbedaan bermakna antara adanya tanaman bakau dengan keberadaan jentik Anopheles di tempat perindukan.

\subsection{Hubungan antara Lumut dengan Keberadaan Jentik Anopheles}

Untuk keberadaan lumut dalam tempat perindukan, sebagian besar tidak ditemukan adanya lumut $(63,3 \%)$

Tabel 12. Keberadaan Jentik Anopheles

\begin{tabular}{|c|c|c|c|c|c|}
\hline \multirow{2}{*}{ Lumut } & \multicolumn{2}{|c|}{ Keberadaan Jentik Anopheles } & \multirow{2}{*}{ Total } & \multirow{2}{*}{$\begin{array}{c}\text { OR } \\
(95 \% \mathrm{CI})\end{array}$} & \multirow{2}{*}{$\mathrm{P}$ value } \\
\hline & $\mathrm{Ya}$ & Tidak & & & \\
\hline \multirow{2}{*}{ Ada } & 4 & 12 & 16 & \multirow{6}{*}{$\begin{array}{r}1,762 \\
(0,439- \\
7,076)\end{array}$} & \multirow{6}{*}{0,669} \\
\hline & $25,0 \%$ & $75,0 \%$ & $100,0 \%$ & & \\
\hline Tidak Ada & 7 & 37 & 44 & & \\
\hline 110ак Ada & $15,9 \%$ & $84,1 \%$ & $100,0 \%$ & & \\
\hline \multirow{2}{*}{ Total } & 11 & 49 & 60 & & \\
\hline & $18,3 \%$ & $81,7 \%$ & $100,0 \%$ & & \\
\hline
\end{tabular}

Analisis hubungan antara ada tidaknya lumut dengan keberadaan jentik dalam tempat perindukan menunjukkan bahwa dari lokasi dimana ditemukan lumut pada tempat perindukan, sebanyak empat tempat perindukan ditemukan adanya jentik (25\%), sedangkan pada lokasi dimana tidak ada lumut sebanyak 7 lokasi perindukan $(15,9 \%)$ ditemukan adanya jentik Anopheles. Hasil uji statistik diperoleh nilai P value 
sebesar 0,669 maka, dapat disimpulkan bahwa dengan tingkat kepercayaan 95\% tidak ada hubungan antara ada tidaknya lumut dengan keberadaan jentik Anopheles di tempat perindukan.

\subsection{Hubungan antara Ganggang dengan Keberadaan Jentik Anopheles}

Keberadaan ganggang tidak ditemukan pada lokasi perindukan Anopheles, sedangkan dari keseluruhan lokasi penelitian keberadaan ganggang ditemukan pada 1 (satu) lokasi perindukan

Tabel 13. Keberadaan Jentik Anopheles

\begin{tabular}{ccccccc}
\hline \multirow{2}{*}{ Ganggang } & \multicolumn{2}{c}{ Keberadaan Jentik Anopheles } & & OR & P value \\
\cline { 2 - 3 } & Ya & Tidak & & & & \\
Ada & 0 & 1 & & 1 & & \\
& $0 \%$ & $100,0 \%$ & & $100,0 \%$ & & \\
Tidak Ada & 11 & 48 & & 59 & $1,229(1,088-$ & 1,000 \\
& $18,6 \%$ & $81,4 \%$ & & $100,0 \%$ & $1,389)$ & \\
Total & 11 & 49 & & 60 & & \\
& $18,3 \%$ & $81,7 \%$ & & $100,0 \%$ & & \\
\hline
\end{tabular}

Berdasarkan Keadaan Ganggang di Tempat Perindukan Di Wilayah Kabupaten Timor Tengah Selatan Tahun 2015

Hubungan antara ada tidaknya ganggang dengan keberadaan jentik Anopheles di tempat perindukan menunjukkan dari bahwa 60 tempat perindukan yang ada, yang ada ganggang hanya 1 (satu) tempat perindukan. Sedangkan pada tempat perindukan yang tidak ditemukan ganggang sebanyak 49 (empat puluh sembilan) lokasi (81,7\%) tidak ditemukan adanya jentik Anopheles. Nilai P Value sebesar 1,000 menunjukan bahwa dengan tingkat kemaknaan 95\% dapat dikatakan tidak ada hubungan antara ada tidaknya ganggang di tempat perindukan dengan keberadaan jentik Anopheles di tempat perindukan tersebut.

\subsection{Hubungan antara Ikan Pemakan Jentik dengan Keberadaan Jentik Anopheles}

Pada sebagian besar tempat perindukan tidak ditemukan adanya ikan pemakan jentik $(83,3 \%)$.

Tabel 14. Keberadaan Jentik Anopheles

\begin{tabular}{|c|c|c|c|c|c|}
\hline \multirow{2}{*}{ Ikan Pemakan Jentik } & \multicolumn{2}{|c|}{ Keberadaan Jentik Anopheles } & \multirow{2}{*}{ Total } & \multirow{2}{*}{$\begin{array}{c}\text { OR } \\
(95 \% \mathrm{CI})\end{array}$} & \multirow{2}{*}{$P$ value } \\
\hline & Ya & Tidak & & & \\
\hline \multirow{2}{*}{ Ada } & 8 & 42 & 50 & \multirow{6}{*}{$\begin{array}{c}0,444(0,094- \\
2,093)\end{array}$} & \multirow{6}{*}{0,551} \\
\hline & $16,0 \%$ & $84,0 \%$ & $100,0 \%$ & & \\
\hline Tidak Ada & 3 & 7 & 10 & & \\
\hline 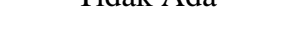 & $30,0 \%$ & $70,0 \%$ & $100,0 \%$ & & \\
\hline \multirow{2}{*}{ Total } & 11 & 49 & 60 & & \\
\hline & $18,3 \%$ & $81,7 \%$ & $100,0 \%$ & & \\
\hline
\end{tabular}

Berdasarkan Keadaan Ikan Pemakan Jentik di Tempat Perindukan Di Wilayah Kabupaten Timor Tengah Selatan Tahun 2015

Hasil analisis hubungan antara ada tidaknya ikan pemakan jentik dengan keberadaan jentik Anopheles di tempat perindukan menunjukkan bahwa pada lokasi dimana terdapat ikan pemakan jentik, angka tempat 
perindukan dengan adanya jentik sebesar $84 \%$ (42 lokasi). Sedangkan pada lokasi dimana tidak ditemukan ikan pemakan jentik, angka tempat perindukan dengan tidak adanya jentik sebesar $70 \%$ (7 lokasi). Nilai $\mathrm{P}$ value sebesar 0,551, maka dapat dikatakan tidak adanya hubungan bermakna antara ada tidaknya ikan pemakan jentik dengan keberadaan jentik Anopheles di tempat perindukan.

\subsection{Hubungan antara Berudu/Anak Katak dengan Keberadaan Jentik Anopheles}

Untuk variabel keberadaan berudu/anak katak pada perindukan Anopheles ditemukan pada 1 lokasi, sedangkan pada keseluruhan lokasi penelitian, ditemukan adanya berudu/anak katak pada 5 (lima) tempat perindukan $(8,3 \%)$.

Tabel 15. Keberadaan Jentik Anopheles

\begin{tabular}{|c|c|c|c|c|c|}
\hline \multirow{2}{*}{ Berudu/Anak Katak } & \multicolumn{2}{|c|}{ Keberadaan Jentik Anopheles } & \multirow{2}{*}{ Total } & \multirow{2}{*}{$\begin{array}{c}\text { OR } \\
(95 \% \mathrm{CI})\end{array}$} & \multirow{2}{*}{$P$ value } \\
\hline & $\mathrm{Ya}$ & Tidak & & & \\
\hline \multirow{2}{*}{$\mathrm{Ya}$} & 10 & 45 & 55 & \multirow{6}{*}{$\begin{array}{c}0,889 \\
(0,089- \\
8,830)\end{array}$} & \multirow{6}{*}{1,000} \\
\hline & $18,2 \%$ & $81,8 \%$ & $100,0 \%$ & & \\
\hline Tidak & 1 & 4 & 5 & & \\
\hline & $20,0 \%$ & $80,0 \%$ & $100,0 \%$ & & \\
\hline \multirow{2}{*}{ Total } & 11 & 49 & 60 & & \\
\hline & $18,3 \%$ & $81,7 \%$ & $100,0 \%$ & & \\
\hline
\end{tabular}

Berdasarkan Keadaan Berudu/Anak Katak di Tempat Perindukan

Hubungan antara ada tidaknya berudu/anak katak dengan keberadaan jentik Anopheles pada tempat perindukan menunjukkan bahwa pada 55 lokasi ditemukan adanya berudu/anak katak, 10 lokasi $(18,2 \%)$ diantaranya ditemukan pula jentik Anopheles. Sedangkan pada lokasi dimana tidak ditemukan adanya berudu/anak katak, 1 (satu) lokasi ditemukan adanya jentik Anopheles. Hasil uji statistik diperoleh nilai $\mathrm{p}=$ 1,000, maka dapat disimpulkan bahwa tidak ada hubungan yang bermakna atau keterkaitan antara ada atau tidak adanya berudu/anak katak dengan keberadaan jentik Anopheles di tempat perindukan.

\section{Simpulan}

1. Dari Total 60 (enam puluh) tempat perindukan, jentik Anopheles ditemukan pada 11 (sebelas) tempat perindukan $(18,3 \%)$, sedangkan pada tempat perindukan lainnya ditemukan jentik lain atau tidak ada jentik.

2. Tempat perindukan sebanyak 9 (sembilan) jenis yaitu bak, drum, tambak, rawa-rawa, sawah, genangan, kali, sumur dan mata air. Dari 11 (sebelas) tempat perindukan dimana jentik Anopheles ditemukan, sebaran berdasarkan jenis tempat adalah sebagai berikut; genangan 36,4\%, kali 27,3\%, rawa-rawa $18,2 \%$, sawah dan bak masing-masing $9,1 \%$.

3. Hasil analisis hubungan antara 18 (delapan belas) variabel independen yaitu (1) suhu udara, (2) suhu air, (3) PH, (4) kelembaban udara, (5) sinar matahari, (6) aliran air, (7) lantai dasar perindukan, (8) luas perindukan, (9) kedalaman perindukan, (10) sifat perindukan, (11) kedalaman perindukan, (12) jarak perindukan, (13) aktivitas masyarakat, (14) bakau, (15) lumut, (16) ganggang, (17) ikan pemakan jentik dan (18) berudu/anak katak dengan 1 (satu) variabel dependen yaitu keberadaan jentik Anopheles didapatkan bahwa terdapat 2 (dua) variabel yang secara signifikan bermakna ada hubungan dengan keberadaan jentik Anopheles yaitu (1) kedalaman air tempat perindukan dan (2) kejernihan air perindukan.

4. Analisis terhadap variabel kejernihan air perindukan didapatkan OR sebesar 6,000 (enam), yang bermakna bahwa tempat perindukan dengan air yang keruh/bercampur lumpur memiliki peluang/risiko 6 (enam) kali lebih tinggi ditemukan adanya jentik Anopheles dibandingkan dengan tempat perindukan 
yang airnya jernih/tidak bercampur lumpur setelah dikontrol dengan17 (tujuh belas) variabel indenpent yang lain.

5. Hasil analisis terhadap kedalaman air perindukan didapatkan nilai $\mathrm{p}$ value 0,000 dengan rata-rata kedalaman air pada tempat perindukan yang tidak ditemukan adanya jentik sebesar 2,0224 sedangkan kedalaman rata-rata perindukanan yang ada jentik adalah 0,5682. Hal ini menunjukkan adanya perbedaan kedalaman rata-rata tempat perindukan yang ada jentik dengan yang tidak ada jentik.

6. Hasil analisis terhadap variabel independen lainnya yang tidak bermakna atau dinyatakan tidak berpengaruh terhadap keberadaan jentik Anopheles pada tempat perindukan, terkait dengan keadaan karakteristik waktu, intensitas dan curah hujan yang turut mempengaruhi karakteristik tempat perindukan selama periode penelitian.

\section{Implementasi}

1. Hasil penelitian ini dapat digunakan sebagai salah satu literatur dalam pengembangan kegiatan penelitian lain yang berhubungan dengan karakteristik jentik Anopheles.

2. Air dengan kondisi keruh/bercampur lumpur agar dialirkan atau ditimbun sehingga tidak menjadi tempat hidup jentik Anopheles. Kondisi air seperti ini dapat berasal dari rawa, lingkungan rumah (buangan kamar mandi/WC), sungai/kali, tapak kaki hewan, dll.

3. Pada lokasi perindukan yang berasal dari aliran kali/sungai dengan genangan kecil yang airnya hampir kering dan banyak dedaunan serta tidak ditemukan adanya binatang air lain, banyak ditemukan jentik Anopheles. Aliran sungai/kali menjelang musim kemarau dimana airnya hampir kering agar ditelusuri dan genangan-genangan kecil ditimbun atau dikeringkan sehingga tidak menjadi tempat hidup jentik Anopheles.

\section{Daftar Pustaka}

Achmadi, U. F. (2008). Manajemen Penyakit Berbasis Wilayah. Jakarta: Penerbit Universitas Indonesia. Anggota IKAPI. (2012). Buku Ajar Malaria I. Malaria, Imunisasi Dan KIA Terpadu. Kupang NTT.

Anies. (2006). Manajemen Berbasis Lingkungan (Solusi Mencegah dan Menanggulangi Penyakit Menular). Jakarta: PT. Elex Media Komputindo.

Ariati, Y., Wigati, W., Andris, H., \& Sukowati, S. (2011). Bioteknologi Vektor Malaria Nyamuk Anopheles Sundaicus Di Kecamatan Nongsa, Kota Batam, Tahun 2008. Indonesian Journal of Health Ecology, 10(1), 79060.

Asa, A. T., Setiani, O., \& Raharjo, M. (2005). Kajian Manajemen Lingkungan Terhadap Kejadian Malaria di Daerah Endemis, Kecamatan Kakuluk Mesak, Kabupaten Belu. Jurnal Kesehatan Lingkungan Indonesia, 4(2), 49-54.

Bustan, Ruslan, Erniwati. (2012). Karakterstik Tempat Perkembangbiakan Larva Anopheles di Desa Bulubete Kecamatan Dolo Selatan Kabupaten Sigi Provinsi Sulawesi Tengah. Tesis. Makasar: Universitas Hasanudin.

Departemen Kesehatan RI, Ditjen PPM \& PL. (2010). Pencegahan dan Penanganan Malaria Selama Kehamilan.

Departemen Kesehatan RI, Ditjen PPM \& PL. (2011). Pedoman Penatalaksanaan Kasus Malaria di Indonesia.

Departemen Kesehatan RI, Ditjen PPM\& PL. (1985). Vektor Malaria di Indonesia.

Departemen Kesehatan RI, Ditjen PPM\& PL. (1999). Kunci Bergambar Anopheles Dewasa di Indonesia.

Departemen Kesehatan RI, Ditjen PPM\& PL. (1999). Modul Pemberantasan Vektor.

Dhewantara, P. W., Astuti, E. P., \& Pradani, F. Y. (2013). Studi Bioekologi Nyamuk Anopheles sundaicus di Desa Sukaresik Kecamatan Sidamulih Kabupaten Ciamis. Bulletin Penelitian Kesehatan, 41(1), 2636. 
Ernamaiyanti, E., Kasry, A., \& Abidin, Z. (2010). Faktor-Faktor Ekologis Habitat Larva Nyamuk Anopheles di Desa Muara Kelantan Kecamatan Sungai Mandau Kabupaten Siak Provinsi Riau Tahun 2009. Jurnal Ilmu Lingkungan, 4(02), 92-102.

Gandahusada, S. (2006). Parasitologi Kedokteran. Jakarta: Fakultas Kedokteran Universitas Indonesia.

Harmendo. (2008). Faktor risiko Kejadian Malaria Di wilayah Kerja Puskesmas Kenanga Kecamatan Sungailiat Kabupaten Bangka. Tesis. Semarang: Universitas Diponegoro.

Husin H. (2007). Analisis Faktor Resiko Kejadian Malaria Di Puskesmas Marindu Kota Bengkulu. Tesis Semarang: Program Pascasarjana Universitas Diponegoro.

Mading, M. (2013). Fauna Dan Karakteristik Tempat Perkembangbiakan Nyamuk Amopheles Sp. Di Desa Selong Belanak Kabupaten Lombok Tengah. Jurnal Penyakit Bersumber Binatang, 1(1), 41-53.

Murti, B. (2003). Prinsip dan metode riset epidemiologi. Yogyakarta: Universitas Gadjah Mada Press.

Notoadmodjo, S. (2012). Metode Penelitian Kesehatan. Jakarta: Rineka Cipta, Jakarta.

Notoatmodjo, Soekidjo, dan Wuryaningsih, E. (2000). Pendidikan Promosi dan Perilaku Kesehatan. Jakarta: Fakultas Kesehatan Masyarakat Universitas Indonesia.

Prabowo, A. (2004). Malaria, Mencegah dan Mengatasinya. Jakarta: Puspa Swara.

Ririh, Y. (2011). Pengendalian Vektor Dan Rodent. Surabaya: Pustaka Melati.

Riyanto, A. (2012). Penerapan analisis multivariat dalam penelitian kesehatan. Yogyakarta: Nuha Medika.

Sugyono. (2012). Metode penelitian kualitatif kuantitatif. Jakarta: R\&D.

Supranto, J. (2004). Analisis Multivariat, Arti \& Interpretasi. Jakarta: Rhineke Cipta PT.

Sutanto P. H. (2007). Analisis Data Kesehatan. Jakarta: Fakultas Kesehatan Masyarakat Universitas Indonesia.

Widarjono, A. (2010). Analisis statistika multivariat terapan. Yogyakarta: UPP STIM YKPN. 